\title{
Yield Improvement in Cucumber through Integrated Nutrient Management Practices in Coastal Plain Zone of Odisha, India
}

\author{
S.K. Dash ${ }^{1}$, G.S. Sahu ${ }^{1}$, S. Das ${ }^{1}$, S. Sarkar ${ }^{1}$, L. Tripathy ${ }^{2}$, \\ S.R. Pradhan ${ }^{3 *}$ and A. Patnaik ${ }^{1}$ \\ ${ }^{1}$ Directorate of Research, AICRP on Vegetable Crops, OUAT, Bhubaneswar, Odisha, India \\ ${ }^{2}$ College of Forestry, OUAT, Bhubaneswar, Odisha, India \\ ${ }^{3}$ Department of Vegetable Science, CA, OUAT, Bhubaneswar, Odisha, India
}

*Corresponding author

\section{A B S T R A C T}

\section{Key words}

Cucumber,

Azotobacter,

Integrated nutrient

management

Article Info

Accepted:

24 January 2018

Available Online:

10 February 2018
The experiment on yield improvement in cucumber through integrated nutrient management practices was conducted in a randomised block design with three replications under All India Coordinated Research Project on Vegetable Crops at Central Research Station OUAT, Bhubaneswar. Application of half rec. NPK + FYM @ 10 t/ha + Vermi @ $2 \mathrm{t} / \mathrm{ha}+$ Biofertilizer (4.0 kg Azotobacter/ha+ $4.0 \mathrm{~kg}$ PSB/ha) i.e. T11 had the greatest impact on fruit weight invariably in all the experimental years. T11 recorded average fruit weight of $174.84 \mathrm{~g}, 180.45 \mathrm{~g}$ and $171.40 \mathrm{~g}$ during 2014, 2015 and 2016 respectively. From pooled data (Table 6) over three years it was observed that amongst the treatments T11 recorded the highest yield (105.44 q/ha) whereas the lowest yield was recorded in $\mathrm{T} 2$ $(56.70 \mathrm{q} / \mathrm{ha})$. From the present investigation it may be suggested that application of half rec. NPK + FYM @ 10 t/ha + Biofertilizers (4.0 kg Azotobacter/ha + 4.0 kg PSB/ha) i.e., T8 was the best integrated nutrient management practice to be followed.

\section{Introduction}

Cucumbers (Cucumis sativus) are often eaten as a vegetable but they are scientifically considered a fruit as they contain enclosed seeds and develop from a flower. Cucumbers are extremely beneficial for overall health, especially during the summer since they are mostly made of water and important nutrients that are essential for the human body. The flesh of cucumbers is rich in vitamin $\mathrm{A}$, vitamin $\mathrm{C}$, and folic acid while the hard skin of cucumbers is rich in fibre and a range of minerals include magnesium, molybdenum, and potassium. Additionally, cucumber contains silica, a trace mineral that contributes greatly to strengthening our connective tissues. Cucumbers are known to heal many skin problems, under eye swelling and sunburn. Cucumbers also contain ascorbic and caffeic acids which prevent water loss, therefore cucumber is frequently applied topically to burns and dermatitis.

Cucumber is a widely demanded fruit in Odisha market as it is consumed throughout the year. Integrated nutrient management (INM) is one important technology to be 
followed by the farmers to get high yield with less detrimental effect on soil health. The continuous use of high level of chemical fertilizers leads to decrease the nutrient uptake efficiency of plants, resulting in either stagnation or decrease in yield and also causing environmental pollution (Singh and Kalloo, 2000). In recent times the concept of Integrated Nutrient Management system has been receiving increasing attention worldwide obviously for reasons of economization of fertilizer usage, safeguarding and ensuring scientific management of soil health for optimum growth, yield and quality of crops in an integrated manner in a specific agroecological situations, through balanced use of organic and inorganic plant nutrients; so that one can harvest good yield without deteriorating soil health. Integrated Nutrient Management (INM) implies the most efficient use and management of organic, inorganic and biological sources of major nutrients as well as micronutrients to attain higher levels of crop productivity and to maintain the fertility of the soil. Research works on INM system for cucumber crop is scanty. Therefore the present investigation is undertaken to study the effect of different INM practices on cucumber production.

\section{Materials and Methods}

The experiment was conducted in a randomised block design with three replications under All India Coordinated Research Project on Vegetable Crops at Central Research Station OUAT, Bhubaneswar (East and SE Coastal Plain Zone, $20^{\circ} 15^{\prime} \mathrm{N}$ latitude and $85^{\circ} 52^{\prime} \mathrm{E}$ longitude) during the year 2014, 2015 and 2016. This experiment includes eleven treatments like T1: FYM @ 20 t/ha, T2: Vermicompost @ 4 t/ha, T3: Rec. NPK through fertilizers, T4: FYM @ 10 t/ha + Biofertilizers $(4.0 \mathrm{~kg}$ Azotobacter $/ \mathrm{ha}+4.0 \mathrm{~kg}$ PSB/ha); T5: Vermicompost @ 2 t/ha +
Biofertilizers (4.0 kg Azotobacter $/ \mathrm{ha}+4.0 \mathrm{~kg}$ PSB/ha), T6: Half rec. NPK +Biofertilizers (4.0 kg Azotobacter/ha+ $4.0 \mathrm{~kg}$ PSB/ha), T7: Half rec. NPK + vermicompost @ 2 t/ha + Biofertilizers (4.0 kg Azotobacter $/ \mathrm{ha}+4.0 \mathrm{~kg}$ PSB/ha), T8: Half rec. NPK + FYM @ 10 t/ha + Biofertilizers (4.0 kg Azotobacter $/ \mathrm{ha}+4.0 \mathrm{~kg}$ PSB/ha), T9: Rec. NPK + FYM @ 10 t/ha + Biofertilizers (4.0 kg Azotobacter $/ \mathrm{ha}+4.0 \mathrm{~kg}$ PSB/ha) T10: Rec. NPK + Vermi @ 2 t/ha + Biofertilizers (4.0 kg Azotobacter $/ \mathrm{ha}+4.0 \mathrm{~kg}$ PSB/ha), T11: Half rec. NPK + FYM @ 10 t/ha+Vermicompost @ 2 t/ha + Biofertilizer (4.0 kg Azotobacter/ha+ $4.0 \mathrm{~kg} \mathrm{PSB} / \mathrm{ha})$. Cucumber seeds of variety Star Seven were sown at a spacing of $2 \mathrm{~m} \times 50 \mathrm{~cm}$. The plot size was $3 \times 2.7 \mathrm{~m}^{2}$. During the year, 2014 sowing was done on 28.03.14; during 2015 sowing was done on 23.05.15; during 2016 sowing was done on 12.03.16. To study the effect of integrated nutrient management we recorded observations on yield and yield attributing traits like days to first fruit harvest, crop duration, fruit length, fruit girth, number of fruits per plant, average fruit weight and fruit yield by selecting five plants randomly from each treatment and replications. Data were analysed following SAS 9.3 version.

\section{Results and Discussion}

Pooled analysis of variance indicated significant variation among the treatments in respect of all the traits except days to first fruit harvest and crop duration in days (Table 1). Days to first fruit harvest is shown in Figure 1. From the figure it was revealed that during the year 2014, days to first fruit harvest was maximum in T3 (55.33 days) and minimum in both T10 and T11 (49.33 days). During 2015, the maximum day taken for fruit harvest was recorded in T10 (51.33 days) followed by T9 (50.67 days) and this may be due to delay sowing. During 2016, the maximum days taken for fruit harvest was recorded in T9 (51.67 days) followed by T5 (51.50 days). 
During the year 2014, the maximum crop duration (81.33 days) was observed in T8 (Half rec. NPK + FYM @ 10 t/ha + Biofertilizers) followed by T6 (81.00 days) whereas T2 (Vermicompost @ 4 t/ha) recorded the minimum crop duration (78.33 days). From Figure 2, it was observed that during 2015, the crop duration was lower as compared to 2014 and 2016 and this may be due to late planting. The maximum crop duration was observed in both $\mathrm{T} 11$ and $\mathrm{T} 9$ (71.00 days). Similarly during 2016, the maximum crop duration was observed in both T11 and T9 (75.00 days). Pooled mean indicated that $\mathrm{T} 9$ recorded the maximum crop duration (75.44 days).

The treatments showed significant variation in their effect on fruit length (Table 2). During the year 2014, the highest fruit length (17.63 $\mathrm{cm})$ was realised by applying half recommended NPK + FYM @ 10 t/ha + Vermicompost@ 2 t/ha + Biofertilizer (T11) whereas the lowest fruit length $(15.27 \mathrm{~cm})$ was obtained by applying Vermicompost @ 4 t/ha (T2). Application of Vermicompost @ 4 t/ha, FYM @ 10 t/ha + Biofertilizers and Vermicompost@2t/ha + Biofertilizers were not at par with half rec. NPK + FYM @ 10 t/ha+Vermicompost@ 2 t/ha + Biofertilizer. During 2015, all the treatments were at par with T3 (rec. NPK through fertilizers) which produced the highest fruit length of $15.40 \mathrm{~cm}$ except T2 (Vermicompost @ 4 t/ha). Again during the year 2016, the highest fruit length of $16.50 \mathrm{~cm}$ was obtained with T3 (rec. NPK through fertilizers) and the lowest fruit length $(14.88 \mathrm{~cm})$ with T4 (FYM @ 10 t/ha + Biofertilizers). Mean data showed that application of T3 had the best effect on fruit length and it was at par with T1(FYM @ 20 t/ha), T8 (Half rec. NPK + FYM @ 10 t/ha + Biofertilizers), T9 (Rec. NPK + FYM @ 10 t/ha + Biofertilizers), T10 (Rec. NPK + Vermi @ $2 \mathrm{t} / \mathrm{ha}+$ Biofertilizers) and T11 (Half rec. NPK + FYM@10 t/ha +Vermi@2t/ha +
Biofertilizer). The effect of different treatments on fruit girth is presented in Table 3.

Significant differences were observed among the treatments during the year 2014, 2015 and in pooled data. During the year 2014, application of T9 (Rec. NPK + FYM @ 10 $\mathrm{t} / \mathrm{ha}+$ Biofertilizers) recorded the highest fruit girth $(15.45 \mathrm{~cm})$ and it was at par with all other treatments except T8 $(13.12 \mathrm{~cm})$. But interestingly during the year 2015, it was observed that application of half rec. NPK + FYM @ 10 t/ha + Biofertilizers (T8) recorded the highest fruit girth $(14.21 \mathrm{~cm})$ and at par with all the treatments except T9 (Rec. NPK + FYM @ $10 \mathrm{t} / \mathrm{ha}+$ Biofertilizers). During the year 2016, the highest fruit girth was observed in T11 and the lowest in T9 and there were no significant differences among the treatments. Mean data showed that T5 had the highest effect on fruit girth $(14.69 \mathrm{~cm})$ and it was at par with T1, T2, T3, T4 and T11.

The most important yield attributing trait is number of fruits per plant and the data recorded on it is presented in Table 4. Significant differences were observed among the treatments during the year 2014, 2015, 2016 and in pooled mean data. During the year 2014, the highest number of fruits/plant (5.40) was obtained by applying FYM @ 10 t/ha + Biofertilizers (4.0 kg Azotobacter/ha+ $4.0 \mathrm{~kg} \mathrm{PSB} / \mathrm{ha}$ ) i.e. T4 and this treatment was at par with T1, T8, T9, T10 and T11. During the year 2015, higher number of fruits was obtained in each treatment as compared to the year 2014. The highest number of fruits/plant (7.50) was obtained by applying FYM @ 10 t/ha + Biofertilizers i.e. T4 and Half rec. NPK +FYM@10 t/ha +Vermicompost@ 2 t/ha + Biofertilizer $(4.0 \mathrm{~kg}$ Azotobacter $/ \mathrm{ha}+4.0 \mathrm{~kg}$ $\mathrm{PSB} / \mathrm{ha}$ ) i.e. T11 and these two were at par with all other treatments except T3 and T6 (Fig. 3). 
Table.1 Pooled analysis of variance for different yield attributing traits

\begin{tabular}{|l|c|c|c|}
\hline \multicolumn{1}{|c|}{ Character } & \multicolumn{3}{|c|}{ MS } \\
\cline { 2 - 4 } & Treatment & Year & Tr. x Yr. \\
\hline Fruit length & DF(10) & DF(2) & DF (20) \\
\hline Fruit girth & $1.343^{*}$ & $12.023^{*}$ & $0.042(\mathrm{~ns})$ \\
\hline Number of Fruit/plant & $0.594^{*}$ & $4.554^{*}$ & $0.255(\mathrm{~ns})$ \\
\hline Average Fruit weight (g) & $0.441^{*}$ & $12.827^{*}$ & $0.037(\mathrm{~ns})$ \\
\hline Fruit yield (q/ha) & $865.190^{*}$ & $109.711^{*}$ & $38.068(\mathrm{~ns})$ \\
\hline
\end{tabular}

Table.2 Impact of INM on Fruit Length $(\mathrm{cm})$ in Cucumber

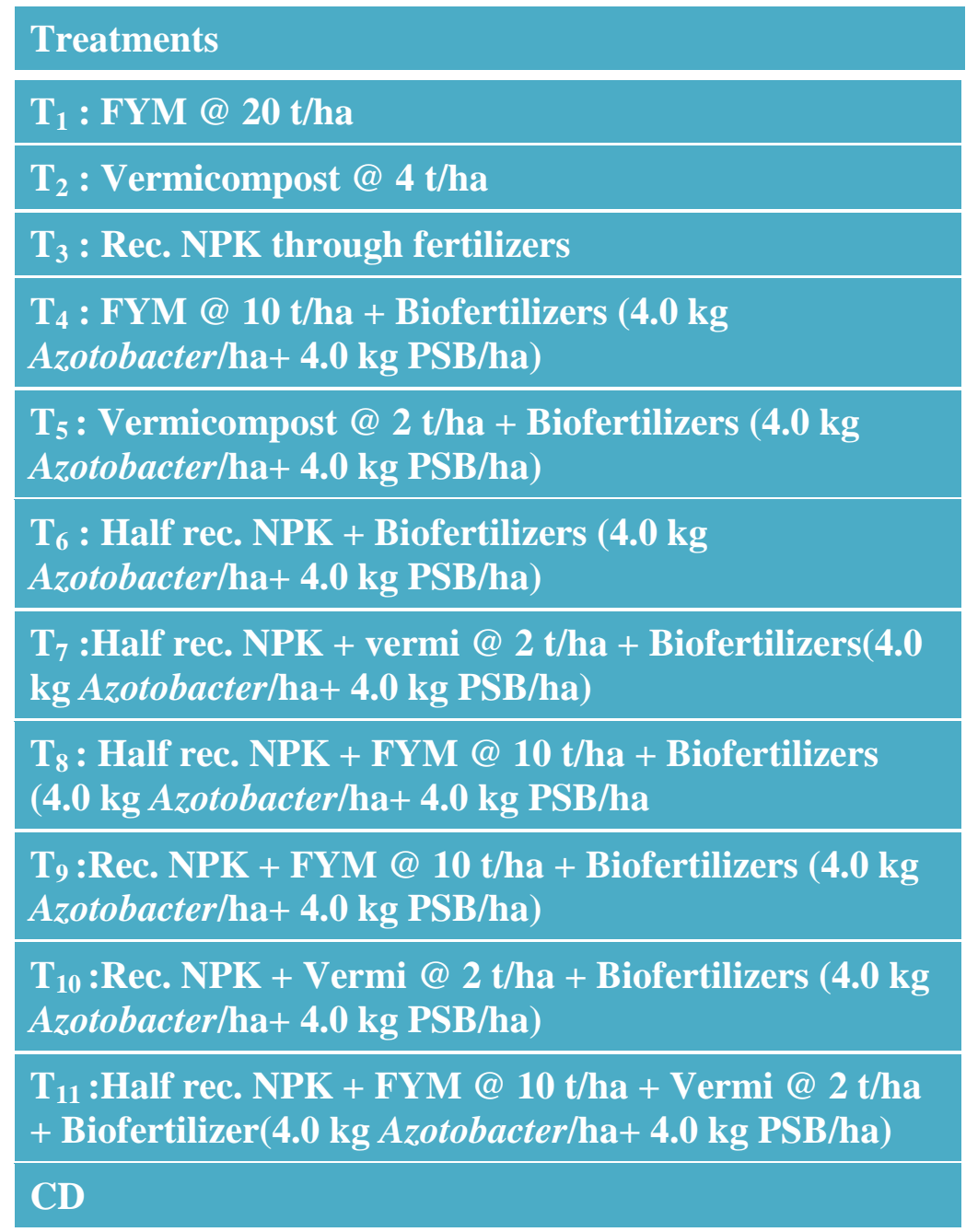

\begin{tabular}{|l|l|l|l|}
\hline 2014 & 2015 & 2016 & Mean \\
\hline 17.29 & 15.09 & 16.19 & 16.19 \\
\hline 15.27 & 13.07 & 14.17 & 14.17 \\
\hline 17.60 & 15.40 & 16.50 & 16.50 \\
\hline 16.05 & 13.91 & 14.88 & 14.95 \\
\hline 15.89 & 14.76 & 15.32 & 15.32 \\
\hline 16.79 & 14.28 & 15.53 & 15.53 \\
\hline 16.23 & 14.23 & 15.23 & 15.23 \\
\hline 16.78 & 14.37 & 15.57 & 15.57 \\
\hline 16.76 & 15.13 & 15.94 & 15.94 \\
\hline 17.26 & 15.35 & 16.30 & 16.30 \\
\hline 17.63 & 14.96 & 16.29 & 16.29 \\
\hline & & & \\
\hline 1.62 & 1.99 & $\mathbf{0 . 9 3 2}$ \\
\hline
\end{tabular}


Table.3 Impact of INM on Fruit girth $(\mathrm{cm})$ in Cucumber

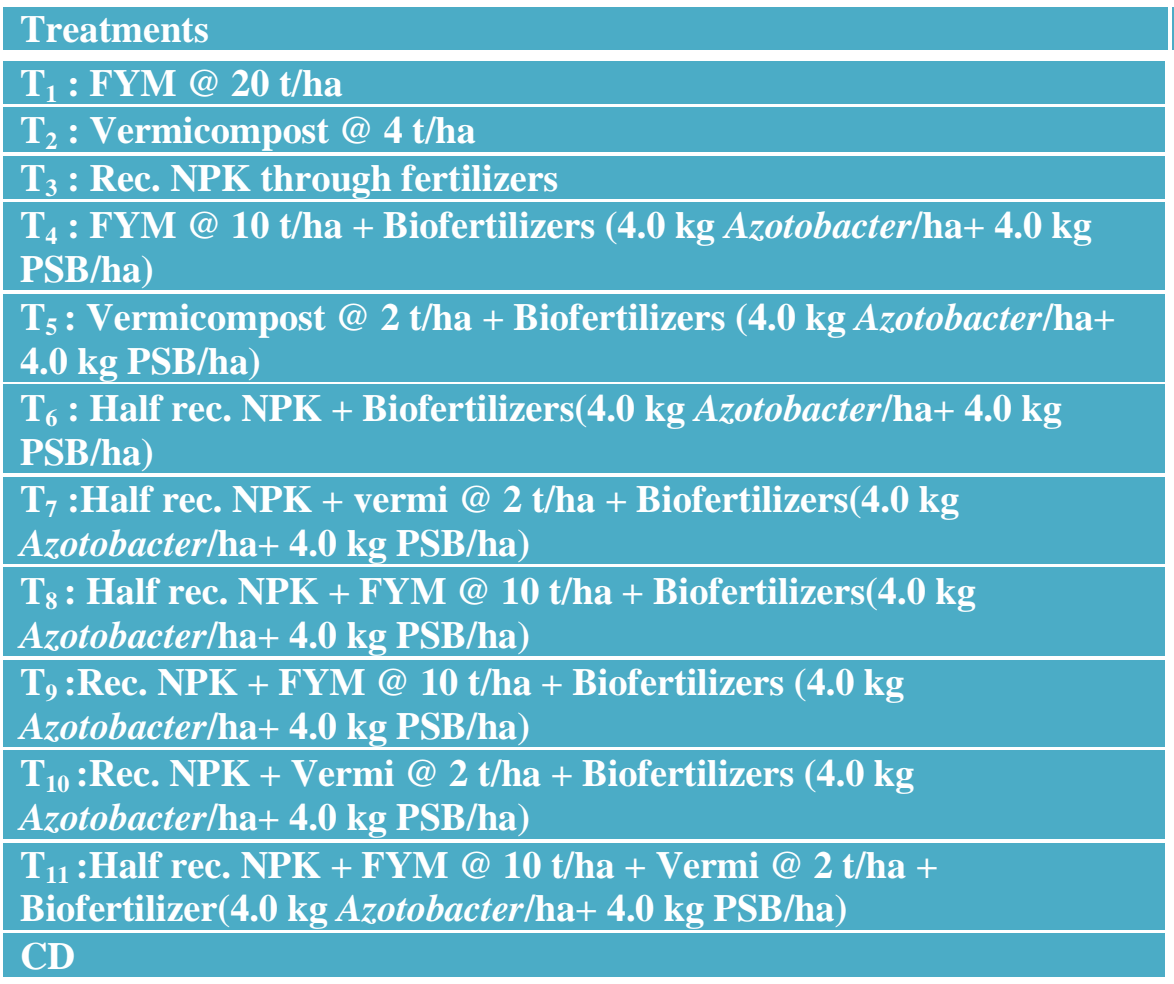

\begin{tabular}{|l|l|l|l|}
\hline 2014 & 2015 & 2016 & Mean \\
\hline 15.17 & 13.95 & 14.56 & 14.56 \\
\hline 15.01 & 12.81 & 13.91 & 13.91 \\
\hline 15.25 & 14.02 & 14.59 & 14.62 \\
\hline 14.60 & 13.42 & 14.01 & 14.01 \\
\hline 15.31 & 14.08 & 14.69 & 14.69 \\
\hline 14.41 & 13.20 & 13.81 & 13.81 \\
\hline 14.35 & 13.25 & 13.84 & 13.81 \\
\hline 13.12 & 14.21 & 13.38 & 13.57 \\
\hline 15.45 & 12.05 & 13.43 & 13.64 \\
\hline 14.16 & 12.91 & 13.52 & 13.53 \\
\hline 15.26 & 14.05 & 14.70 & 14.67 \\
\hline $\mathbf{1 . 4 2}$ & $\mathbf{1 . 4 1}$ & $\mathbf{N S}$ & $\mathbf{0 . 8 5 6}$ \\
\hline
\end{tabular}

Table.4 Impact of INM on Number of Fruits/plant in Cucumber

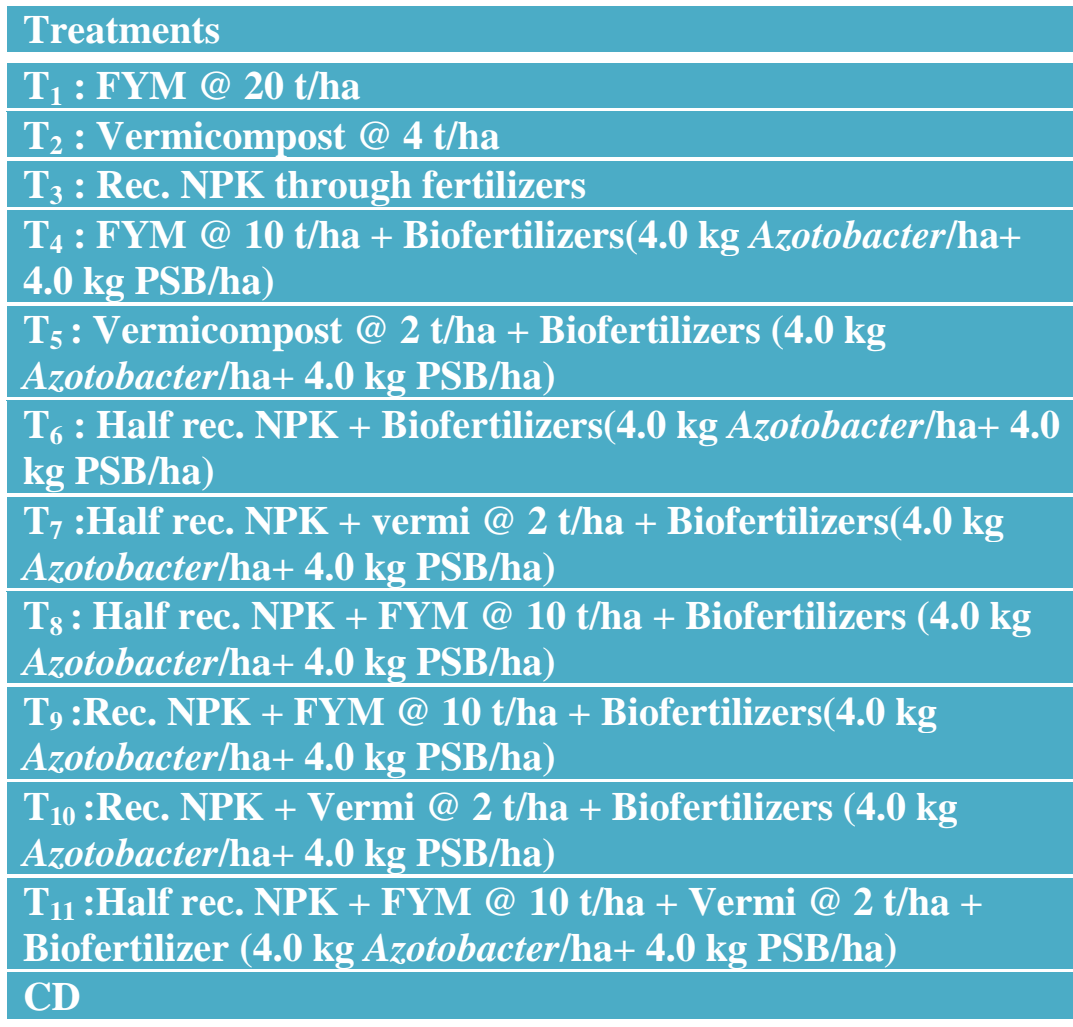

\begin{tabular}{|l|l|l|l|}
\hline 2014 & 2015 & 2016 & Mean \\
\hline 5.10 & 6.70 & 5.06 & 5.62 \\
\hline 4.40 & 6.67 & 5.49 & 5.52 \\
\hline 5.40 & 6.57 & 5.38 & 5.42 \\
\hline 4.50 & 6.67 & 6.14 & 6.35 \\
\hline 4.10 & 6.23 & 5.57 & 5.3 \\
\hline 4.60 & 6.80 & 5.72 & 5.71 \\
\hline 5.20 & 7.47 & 6.13 & 6.27 \\
\hline 5.10 & 7.43 & 6.00 & 6.18 \\
\hline 4.93 & 7.10 & 6.13 & 6.05 \\
\hline 5.30 & 7.50 & 6.37 & 6.39 \\
\hline $\mathbf{0 . 5 7}$ & $\mathbf{0 . 8 3}$ & $\mathbf{0 . 9 8}$ & $\mathbf{0 . 5 6}$ \\
\hline
\end{tabular}


Table.5 Impact of INM on Average Fruit weight (g) in Cucumber

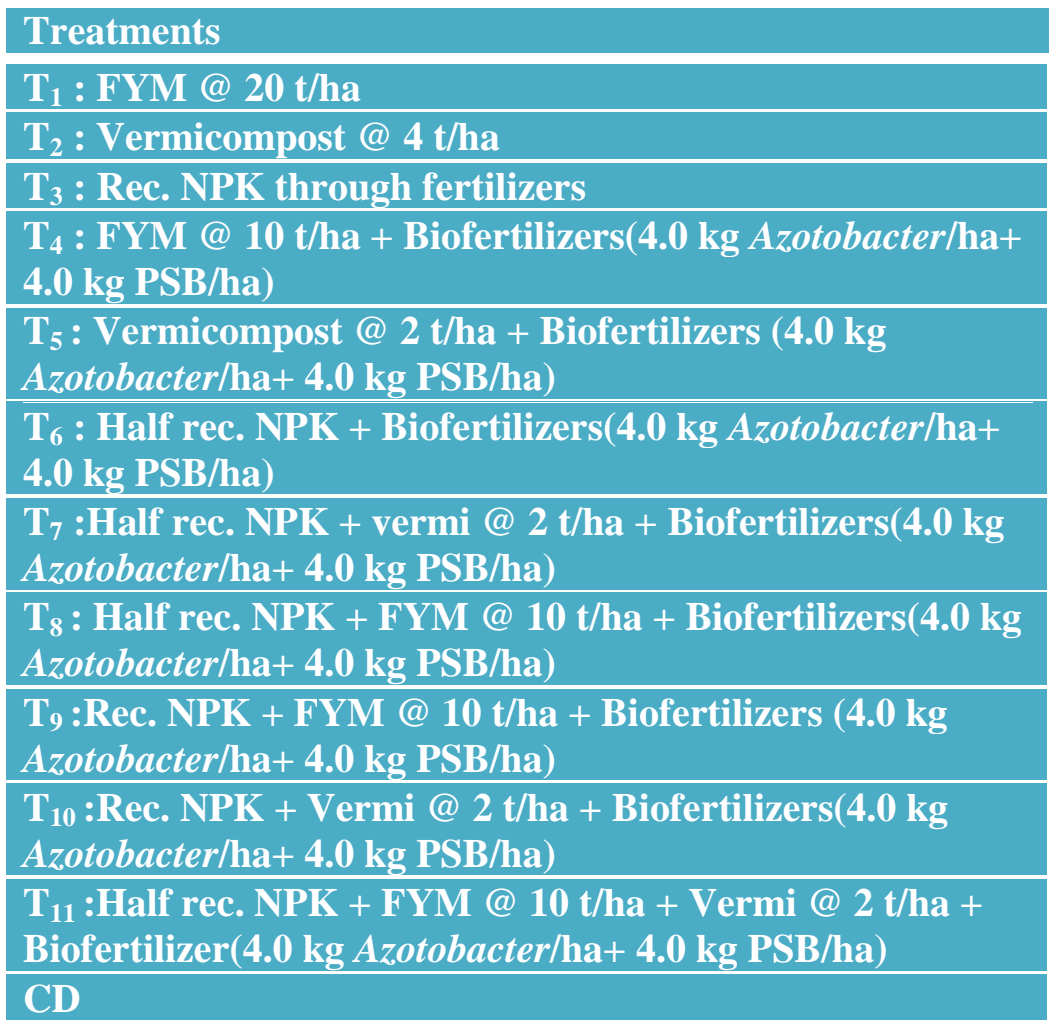

\begin{tabular}{|l|l|l|l|}
\hline 2014 & 2015 & 2016 & Mean \\
\hline 142.16 & 144.53 & 141.49 & 142.73 \\
\hline 108.24 & 108.55 & 104.87 & 107.22 \\
\hline 137.78 & 137.32 & 134.35 & 136.48 \\
\hline 140.11 & 140.32 & 137.53 & 139.32 \\
\hline 117.66 & 122.66 & 116.26 & 118.86 \\
\hline 131.21 & 152.90 & 141.69 & 141.93 \\
\hline 126.92 & 154.22 & 141.46 & 140.87 \\
\hline 167.31 & 151.04 & 154.70 & 157.68 \\
\hline 136.94 & 157.37 & 146.98 & 147.10 \\
\hline 139.53 & 136.86 & 139.35 & 138.58 \\
\hline 174.84 & 180.45 & 171.40 & 175.56 \\
\hline $\mathbf{2 2 . 6 6}$ & $\mathbf{2 6 . 7 2}$ & $\mathbf{1 9 . 1 4}$ & $\mathbf{1 1 . 9 2}$ \\
\hline
\end{tabular}

Table.6 Impact of INM on Yield (q/ha) in Cucumber

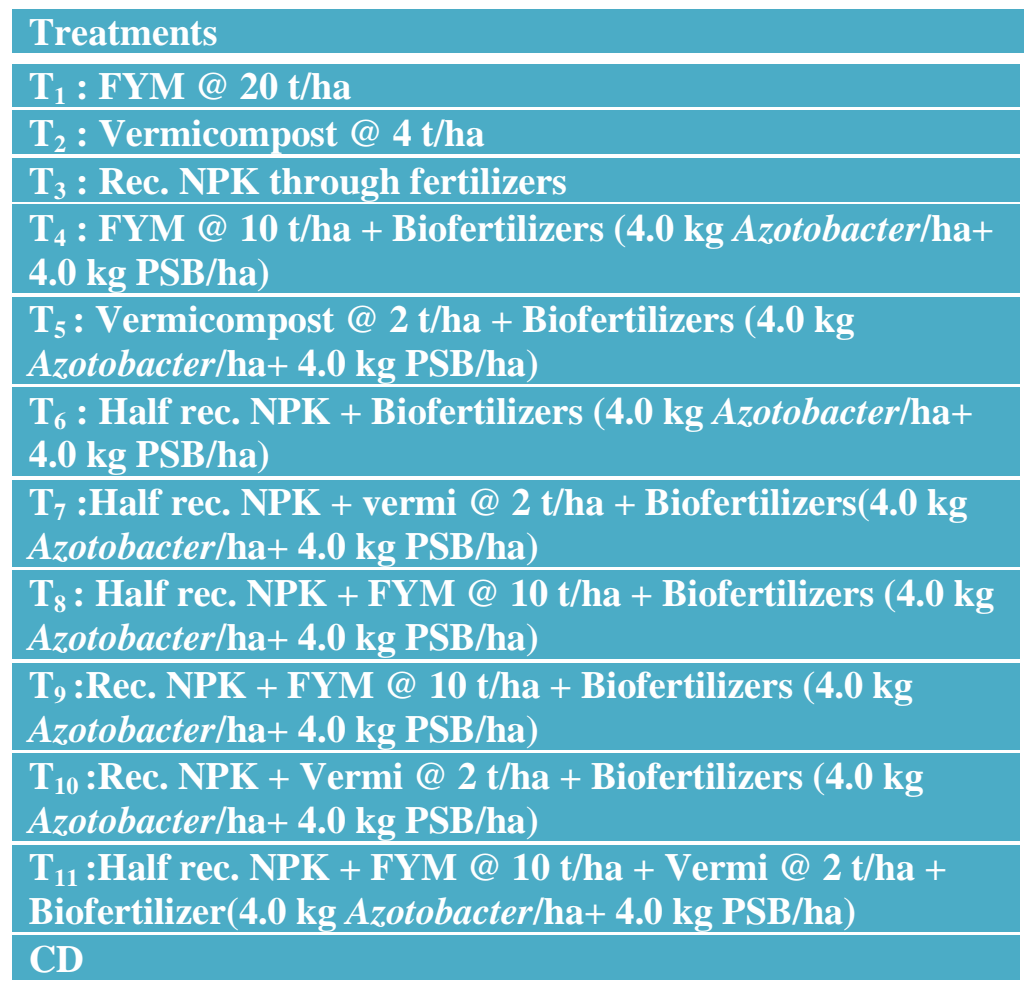

\begin{tabular}{|l|l|l|l|}
\hline 2014 & 2015 & 2016 & Mean \\
\hline 80.97 & 96.24 & 84.2 & 87.14 \\
\hline 74.78 & 62.58 & 56.30 & 56.70 \\
\hline 86.86 & 70.61 & 76.92 & 79.80 \\
\hline 59.28 & 70.03 & 63.21 & 64.17 \\
\hline 63.29 & 75.22 & 71.11 & 69.87 \\
\hline 68.95 & 81.63 & 76.79 & 75.79 \\
\hline 96.01 & 93.40 & 87.66 & 92.36 \\
\hline 79.12 & 113.61 & 90.5 & 94.41 \\
\hline 78.89 & 93.57 & 76.55 & 83.00 \\
\hline 100.48 & 119.04 & 96.79 & 105.44 \\
\hline $\mathbf{1 2 . 7 3}$ & $\mathbf{2 8 . 8 5}$ & $\mathbf{1 4 . 0 7}$ & $\mathbf{1 7 . 4 5}$ \\
\hline
\end{tabular}


Fig.1 Days to first fruit harvest during the year 2014, 2015 and 2016

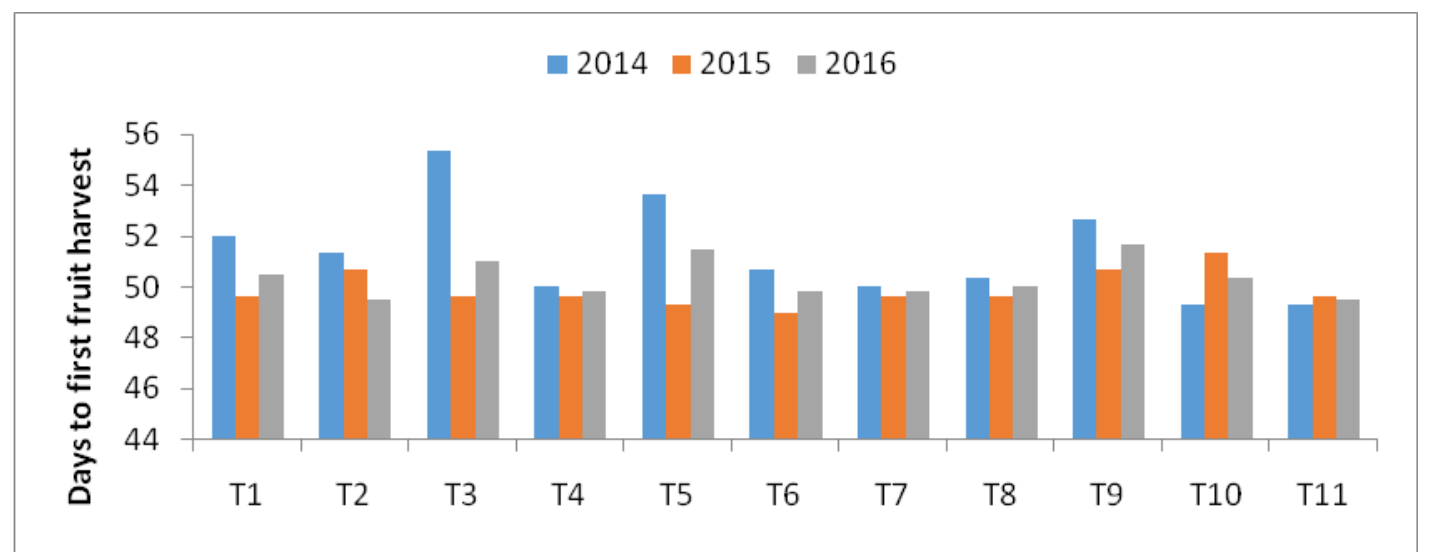

Fig.2 Crop duration in days during the year 2014, 2015 and 2016

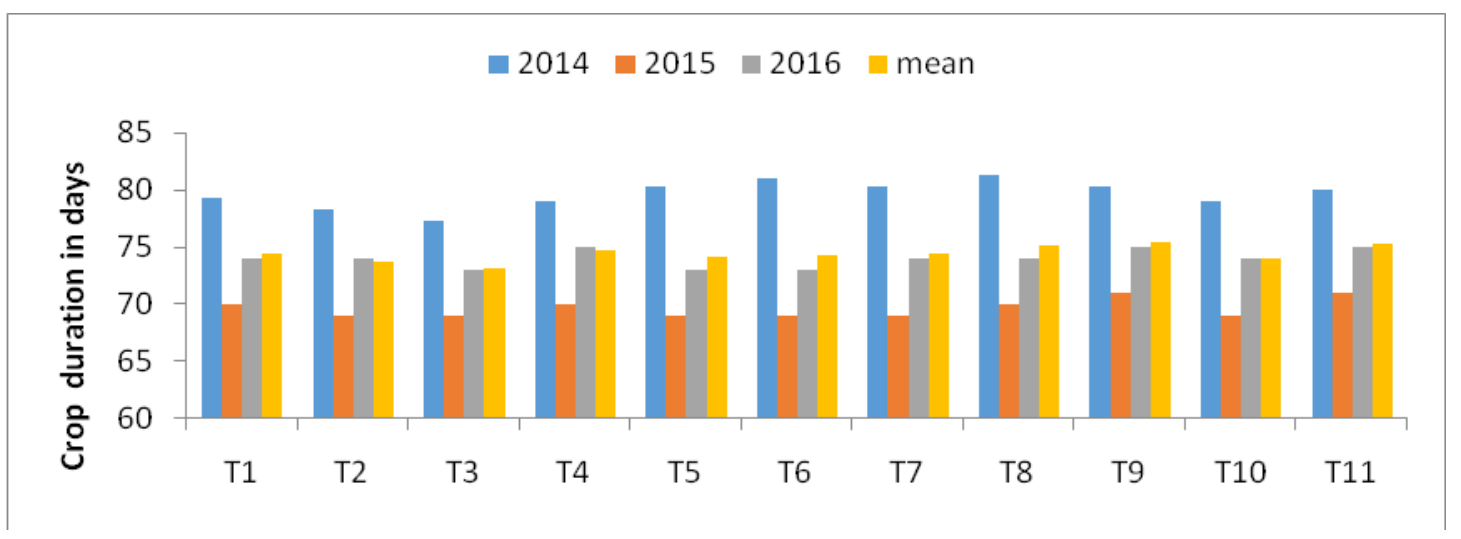

Fig.3 Scatter plot of Yield (q/ha) and B: C ratio of different treatment

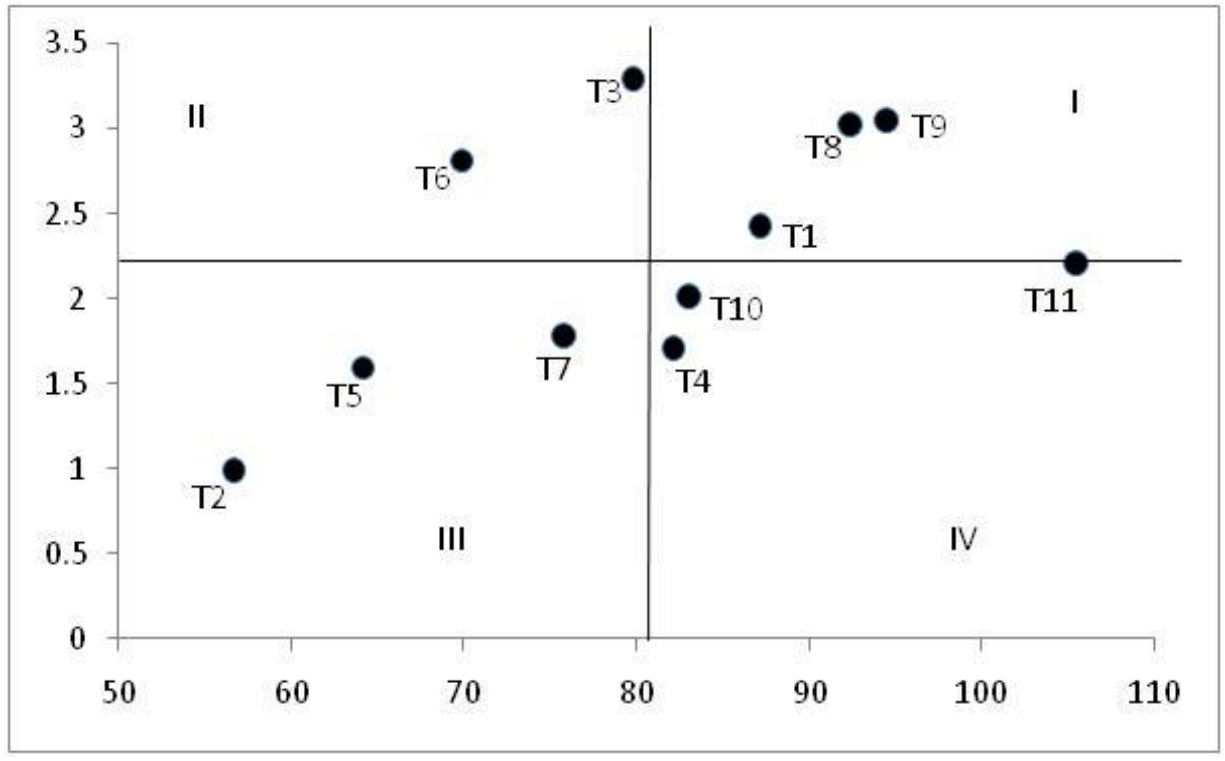


During 2016, T11 recorded the maximum number of fruits per plant (6.37) and it was at par with all other treatments except $\mathrm{T} 1$ and T3. Mean data reflected the best result of T11 that had given the highest number of fruits per plant (6.39) this treatment was at par with T4, T8, T9 and T10.

The effect of integrated nutrient management practices on average fruit weight is presented in Table 5. Significant differences were observed among different management practices during the year 2014, 2015, 2016 and in mean data. Application of half rec. NPK + FYM@10 t/ha + Vermic @ 2 t/ha + Biofertilizer $(4.0 \mathrm{~kg}$ Azotobacter $/ \mathrm{ha}+4.0 \mathrm{~kg}$ $\mathrm{PSB} / \mathrm{ha}$ ) i.e T11 had the greatest impact on fruit weight invariably in all the experimental years. T11 recorded average fruit weight of $174.84 \mathrm{~g}, 180.45 \mathrm{~g}$ and $171.40 \mathrm{~g}$ during 2014 , 2015 and 2016 respectively.

From pooled data (Table 6) over three years it was observed that amongst the treatments T11 recorded the highest yield (105.44 q/ha) whereas the lowest yield was recorded in T2 (56.70 q/ha).Comparing the effect of FYM (T1), vermicompost (T2) and chemical fertilizers (T3) it was seen that FYM had the best effect in increasing yield rather than vermicompost and chemical fertilizers. Addition of biofertilizer with the half dose of FYM (T4) could not exceed the effect of full dose of FYM (T1). But addition of biofertilizer with half dose of vermicompost (T5) increased the yield to $13.2 \%$ as compared to full dose of vermicompost alone (T2). When biofertilizer was added to half recommended dose of NPK (T6) the yield was reduced to $12.44 \%$. This result indicated that the combination of biofertilizer with vermicompost had positive effect and combination of biofertilizer with FYM and NPK had antagonistic effect. Addition of half dose of vermicompost (@ 2 tons/ha)with half dose of recommended NPK + biofertilizer resulted in less yield $(75.79 \mathrm{q} / \mathrm{ha})$ as compared to addition of FYM @ 10tons/ha) to half recommended dose of NPK + biofertilizer $(92.36 \mathrm{q} / \mathrm{ha})$. Addition of half FYM to full dose NPK + biofertilizer (T9) recorded more yield $(94.41 \mathrm{q} / \mathrm{ha})$ than addition of half vermicompost to full dose of NPK + biofertilizer ( $83.0 \mathrm{q} / \mathrm{ha})$. This result indicated that vermicompost could not be a substitute of FYM in case of cucumber.

Before taking final decision for recommendation regarding the selection of best treatment it would be worthwhile to consider benefit cost ratio of the treatments. Treatments giving above average fruit yield with high $\mathrm{B}$ : $\mathrm{C}$ ratio would be beneficial for the farmers' community. Scatter plot of average yield and $\mathrm{B}$ : $\mathrm{C}$ ratio indicated that $\mathrm{T} 9$ is the best treatment followed by $\mathrm{T} 8$.

The use of expensive chemical fertilizers as per requirements of crop is not much affordable to the average farmers. Therefore, the application of plant nutrients through organic source like compost, FYM and biofertilizer is advisable (Subbiah et al., 1982).Prasad and Singhania (1989) reported that combination of inorganic fertilizers with organic manures is better than the fertilizer alone in respect of some soil chemical characteristics. Zhang et al., (1988) reported that combined use of NPK fertilizers with organic manure, improved the supply of nutrients in a balanced manner and resulted in better growth, higher yield and better fruit quality of tomato plants. Singh and Kalloo (2000) suggested that better nutrient management may be achieved by the involvement of organic sources, biofertilizers, chemical fertilizers and micronutrients. Sharu and Meerabai (2001) carried out an experiment at Vellayani (Kerala).The highest fruit yield $\left(9.66 \mathrm{t} \mathrm{ha}^{-1}\right.$ ) was obtained with 50 $\%$ poultry manure $+50 \%$ inorganic $\mathrm{N}$. Working with chilli cv. 'Byadgi' under 
Vertisols of Dharwad (Karnataka), Patil and Biradar (2001) recorded the highest fruit yield (19.12 $\mathrm{q} \mathrm{ha}^{-1}$ ) with the application of $200 \%$ RDF + FYM (10 tonne ha $\left.{ }^{-1}\right)+$ VC $\left(2.5 \mathrm{t} \mathrm{ha}^{-1}\right)$. Selvi et al., (2004) reported that combination of NPK (100:50:50 kg ha $\left.{ }^{-1}\right)+$ organic manures (CCP $\left.25 \mathrm{t} \mathrm{ha}^{-1}\right)+$ micronutrients $\left(\mathrm{ZnSO}_{4} @ 25 \mathrm{~kg} \mathrm{ha}{ }^{-1}\right.$ and $\mathrm{FeSO}_{4} @ 50 \mathrm{~kg}$ $\left.\mathrm{ha}^{-1}\right)$ recorded the highest brinjal yield $(21.90$ $\mathrm{t} \mathrm{ha}^{-1}$ ) compared with NPK application alone $\left(16.28 \mathrm{t} \mathrm{ha}^{-1}\right)$.

From the present investigation it may be suggested that application of half rec. NPK + FYM @ 10 t/ha + Biofertilizers (4.0 kg Azotobacter/ha+ $4.0 \mathrm{~kg} \mathrm{PSB} / \mathrm{ha}$ ) i.eT8 is the best integrated nutrient management practice to be followed by the farmers for cucumber production in Coastal plain zone of Odisha.

\section{Acknowledgement}

It is hereby acknowledged that the research work was funded by HQ, AICRP ON Vegetable crops, Varanashi, India.

\section{References}

Patil, K.B. and Biradar, D. P., 2001. Nutrient uptake of chilli as influenced by plant population and integrated nutrient levels in vertisols. J. Maharashtra Agric.
Univ., 26: 337-339.

Prasad, R.A. and Singhania, R.A., 1989. Effects of different types of enriched manures and time of incubation on soil properties. J. Indian Soc. Soil Sci., 37: 319-322.

Selvi, D., Thiageshwari, S., Santhy, P. and Kannan, B. R., 2004. Fruit yield and nutrient uptake by brinjal due to integrated nutrient management in an inceptisol. J. Maharashtra Agric. Univ., 29(2): 220-223.

Sharu, S. R. and Meerabai, M., 2001. Effect of integrated nutrient management on yield and quality in chilli (Capsicum annuum L.), Veg. Sci., 28: 184-185.

Singh, K.P. and Kalloo, G., 2000. Nutrient management in vegetable crops, Fertil. News, 45: 77-81.

Subbiah, K., Helkiah, J., Ravikumar, V. and Rajgolpal, C. K., 1982. Effect of combined application of organic and inorganic fertilizer on yield and nutrient uptake of MDU-1 Chilli, South Indian Hort., 30: 45-47.

Zhang, C.L., Zhang, Y.D., Goa, Z.M., Xu, G.H., Wang, L.Y., Zhou, Q.S., 1988. Effects of combined use of inorganic and organic fertilizers on the yield and quality of tomato, J. Soil Sci., 19 (6): 276-278.

\section{How to cite this article:}

Dash, S.K., G.S. Sahu, S. Das, S. Sarkar, L. Tripathy, S.R. Pradhan and Patnaik, A. 2018. Yield Improvement in Cucumber through Integrated Nutrient Management Practices in Coastal Plain Zone of Odisha, India. Int.J.Curr.Microbiol.App.Sci. 7(02): 2480-2488. doi: https://doi.org/10.20546/ijcmas.2018.702.302 